\title{
Biochemical Changes During Seed Germination of Sterculia urens Roxb.
}

\author{
Botcha SATYANARAYANA ${ }^{1}$, Prattipati SUBHASHINI DEVI'1, Atluru ARUNDHATI² \\ ${ }^{1}$ Andhra University, Department of Biochemistry,Visakhapatnam, India; satyabiochemau@gmail.com,devi.subashini@gmail.com \\ ${ }^{2}$ Andhra University, Department of Botany,Visakhapatnam, India; atluru_arundati@yahoo.com
}

\begin{abstract}
The present study describes biochemical changes taking place during seed germination of Sterculia urens. The levels of proteins, total amino acids, reducing sugars, total soluble sugars and lipids were studied during various stages of seed germination (0-15 days). Total protein content was decreased in cotyledons during seed germination while free amino acid content increased to its maximum extent by $9^{\text {th }}$ day of germination and reverse trend thereafter. The levels of reducing sugars and total soluble sugars increased till $6^{\text {th }}$ day of germination and decreased thereafter. The lipid content was high at initial stages of germination (0-6 days) but gradually decreased by $15^{\text {th }}$ day of germination.
\end{abstract}

Keywords: Sterculia urens, seed germination, proteins, carbohydrates, lipids

\section{Introduction}

Seeds are excellent dispersal units which have emerged in the course of plant evolution. The chemical energy produced during photosynthesis accumulates as seed reserves in multiple forms including carbohydrates, lipids and proteins. In general mobilization of seed reserves following germination is essential for the embryo to complete seedling establishment and, also signals the start of a new life cycle. These seed storage reserves are used directly as a source of nutrition for animals and humans (Khattak et al., 2003; Rao et al., 1998).

Gum karaya (Sterculia urens) is one of the commercially important tree belongs to the family of Sterculiaceae. The tree yields a gum known as gum karaya and this gum has numerous applications in pharmaceutical, dairy and other industries. The natural propagation of Sterculia urens is through seeds. However the seed viability decreases as the time progress. Furthermore its propagation could be done by stem cutting which poses some difficulties. The seeds of Sterculia urens are rich in proteins (35\%), oil (26\%) and carbohydrates (28\%). The seed oil is suitable for edible purposes and soap manufacturing (The wealth of India, 1952).

Good amount of work was done and reported on karaya gum of Sterculia urens. But no reports on biochemical changes during seed germination. The main objective of the present study was an attempt to understand the role of proteins, carbohydrates, lipids and amino acids during various stages of seed germination in Sterculia urens. This study certainly helps in understanding the seed metabolism in Sterculia urens.

\section{Materials and methods}

\section{Seed source}

Seeds were supplied by Kovela foundation a Non Governmental Organization (NGO), Sagarnagar, Visakhapatnam, AP, India. All chemicals used in this study were of analytical grade, and were purchased from Sd Fine Chemicals limited, India.

\section{Germination}

Healthy seeds were selected and were thoroughly washed with running tap water until the outer covering of seed was removed. Then the seeds were rinsed in Tween for 5 minutes followed by running tap water for 5 miuntes and then with $0.1 \% \mathrm{HgCl}_{2}$ for 5 minutes followed by sterile water. The seeds were soaked for 24 hours before they kept for germination (Le Page-Degivry and Garello, 1973) in sterile petri plates with double layered moistened filter paper. The germination was carried out at $30^{\circ} \mathrm{C} 16$ hours light and 8 hours dark (Plummer and Bell, 1995). The number of seeds germinated was counted every day up to 15 days and the Laboratory Germination Count (LGC) was calculated. Radicle emergence of $1 \mathrm{~cm}$ was used as a reference to consider seed germination. The germinated seeds (cotyledons) were used for biochemical analysis with an interval of 3 days $(0,3,6,9,12$ and 15$)$.

\section{Biochemical studies}

Determination of proteins, amino acids, lipids, total soluble sugars, reducing sugars

Each time $(0,3,9,12,15$ days $)$ one gram of germinating seeds (cotyledons) was used to carry out biochemical 
106

analysis. The sample was macerated in motor and pestle with $5 \mathrm{~mL}$ of phosphate buffer. Homogenate was centrifuged at $8000 \mathrm{rpm}$ for 20 minutes. The supernatant was collected and extraction was repeated 4-5times. All the supernatants was pooled and made the volume to $50 \mathrm{~mL}$ with phosphate buffer. One $\mathrm{mL}$ of above extract was taken and $1 \mathrm{~mL}$ of ice cold 20\% TCA was added (Rajaram and Janardhanan, 1990). The pellet was washed twice with acetone and again centrifuged at $8000 \mathrm{rpm}$. Supernatant was discarded and pellet was dissolved in $5 \mathrm{~mL}$ of $0.1 \mathrm{~N} \mathrm{NaOH}$. This was used for protein estimation. Total proteins were estimated by the method of Lowry et al. (1951) using BSA as standard. Each experiment was repeated thrice.

For soluble sugars and free amino acid determinations one gram of germinating seeds (cotyledons) were ground in a mortar and pestle in $5 \mathrm{~mL}$ of $80 \%$ ethanol (v/v) and the mixture was boiled for $10 \mathrm{~min}$ and centrifuged at 2000 $\mathrm{rpm}$ for $10 \mathrm{~min}$, the supernatant was collected and the pellet was reextracted in $5 \mathrm{~mL}$ of hot $80 \%$ ethanol. Supernatants from both extractions were combined, and total soluble sugar and reducing sugars were then determined by the phenol sulfuric acid (Dubois et al., 1956) and Nelson-Somogy (Somogyi, 1952) methods, respectively, using glucose as standard. Free amino acids were determined in the final supernatant by ninhydrin method (Moore and Stein, 1954) using leucine as standard.

Extraction and estimation of lipids was done by the method of Becker et al. (1978). One gram of germinated seeds was ground in mortar and pestle with chloroformmethanol mixture $(2: 1, \mathrm{v} / \mathrm{v})$. For complete extraction the flask was kept at room temperature in the dark. Then chloroform and water $(1: 1, \mathrm{v} / \mathrm{v})$ was added. The solution was subjected to centrifugation, three layers were observed. The methanol layer was discarded and lower organic layer was carefully collected and evaporated in water bath at $60^{\circ} \mathrm{C}$. The weight of the lipid was determined. The results were expressed in terms of weight in $\mathrm{mg}$ of total lipids per gram of fresh tissue.

\section{Statistical analysis}

Each experiment has three replicates and the experiment was repeated thrice and the data was subjected to one way ANOVA using Minitab version 15. A significance level of 0.05 was used for all statistical tests.

\section{Results and discussion}

The total protein content decreased during seed germination in Sterculia urens. The total protein content at the beginning of germination ( 0 day) was $24.5 \mathrm{mg} / \mathrm{gram}$ tissue and decreased to $12.6 \mathrm{mg} / \mathrm{gram}$ tissue at the end of $15^{\text {th }}$ day of germination (Tab. 1, Fig. 1). There was a reduction in the protein content from day 0 to day 15 , with a rapid decrease between $6^{\text {th }}$ to $12^{\text {th }}$ day of germination. The protein depletion in Sterculia urens seeds was very slow within the first 3 days of germination and rapid during the $6^{\text {th }}$ and $15^{\text {th }}$ days of germination coinciding with the hypocotyls extension. A similar result was reported by Yoshida et al. (1997) in Vigna mungo cotyledons during germination. Considerable decreases in the protein content were observed in germinating Lupinus luteus and L. angustifolius (Olczak et al., 1992), soybeans (Tan-Wilson et al., 1996), Bambara groundnuts (Voandzeia subterranea L. Thouans) (Obizaba and Egbuna, 1992), fluted pumpkin (Telfairia occidentalis Hook) (Giami et al., 1999), and sunflower seeds (Helianthus annuus) (Balasaraswathi and Sadasivam, 1997). The loss of proteins from the cotyledons could be due to the transport of amino acids to the growing axes or to respiratory loss, or it might result in the accumulation of free amino acids in the cotyledons. These reports are similar to results of Beevers and Spittoesser (1968) in germinating Peas and in the cotyledons of Mung Bean Seedlings (Kern and Chrispeels, 1978).

Total reducing sugar levels were increased from 0 day $(1.90 \mathrm{mg} / \mathrm{gram})$ up to $6^{\text {th }}$ day $(2.86 \mathrm{mg} / \mathrm{gram})$ of germination and thereafter reverse trend was observed (Tab. 1, Fig. 1). This might be due to mobilization and hydrolysis of seed polysaccharides during seed germination. Polysaccharides can be further hydrolysed by amylases which might be responsible for the increasing total reducing sugar levels in cotyledons during initial stages of seed germination (Bemfeld, 1962). Similar results were reported by Khetarpaul and Chauhan (1990) in Pearl millet.

The total soluble sugars content varied from $1.70 \mathrm{mg} /$ gram seeds to $0.8 \mathrm{mg} /$ gram from 0 day to $15^{\text {th }}$ day of germination (Tab. 1, Fig. 1). During germination, there was a decrease in storage carbohydrates and an increase in total soluble and reducing sugars up to $6^{\text {th }}$ day of seed germination. This might be due to requirement of energy by grow-

Tab. 1. Biochemical studies during seed germination

\begin{tabular}{cccccc}
\hline $\begin{array}{c}\text { Seed germination } \\
\text { (days) }\end{array}$ & $\begin{array}{c}\text { Protein content } \\
(\mathrm{mg} / \mathrm{gram})\end{array}$ & $\begin{array}{c}\text { Reducing sugars } \\
(\mathrm{mg} / \mathrm{gram})\end{array}$ & $\begin{array}{c}\text { Total soluble } \\
\text { sugars }(\mathrm{mg} / \mathrm{gram})\end{array}$ & $\begin{array}{c}\text { Free aminoacids } \\
(\mathrm{mg} / \mathrm{gram})\end{array}$ & $\begin{array}{c}\text { Lipids } \\
(\mathrm{mg} / \mathrm{gram})\end{array}$ \\
\hline 0 & $24.5 \pm 0.28$ & $1.90 \pm 0.04$ & $1.70 \pm 0.05$ & $2.43 \pm 0.08$ & $98.66 \pm 0.66$ \\
3 & $23.53 \pm 0.29$ & $2.23 \pm 0.08$ & $1.93 \pm 0.03$ & $2.70 \pm 0.05$ & $98.33 \pm 1.20$ \\
6 & $17.56 \pm 0.23$ & $2.86 \pm 0.06$ & $2.36 \pm 0.08$ & $3.13 \pm 0.06$ & $90 \pm 1.15$ \\
9 & $15.38 \pm 0.21$ & $1.46 \pm 0.02$ & $1.35 \pm 0.01$ & $3.72 \pm 0.02$ & $75 \pm 1.15$ \\
12 & $14.25 \pm 0.14$ & $1.10 \pm 0.05$ & $1.02 \pm 0.01$ & $2.85 \pm 0.03$ & $60.66 \pm 0.66$ \\
15 & $12.6 \pm 0.15$ & $0.74 \pm 0.03$ & $0.8 \pm 0.05$ & $1.9 \pm 0.05$ & $54 \pm 2.31$ \\
\hline
\end{tabular}

Note: The values represents the Mean \pm SE of three replicates 
ing plant at initial stages of seed germination. These results agree well with the results of Jaya and Venkataraman (1981) in chickpea and greengram and also by in white beans Kon et al. (1973).

Total free amino acid content increased from 0 day $(2.4$ $\mathrm{mg} / \mathrm{gram})$ to $9^{\text {th }}$ day $(3.72 \mathrm{mg} / \mathrm{gram})$ of germination and decreased thereafter (up to 15 days; Tab. 1, Fig. 1). Relatively low content of soluble amino acids were observed in dry seeds but increased levels during seed germination up to $9^{\text {th }}$ day and decreased thereafter. The increase in amino acid content up to $9^{\text {th }}$ day might be due to rapid hydrolysis of proteins, which results in release of free amino acids. The reduction in total amino acids thereafter shows rapid utilization and rapid translocation of amino acids to the growing axes. Similar results were reported by Ali Al-Heal (1992) in Cassia senna seedlings.

Total lipid content reduced from $100 \mathrm{mg} / \mathrm{gram}$ to 49 $\mathrm{mg} / \mathrm{gram}$ from 0 day to $15^{\text {th }}$ day of germination (Tab. 1 , Fig. 2). Approximately 50\% reduction in lipid content was observed by the end of $15^{\text {th }}$ day of germination. Less amount of reduction of lipids and triacylglycerols in the cotyledons indicated their lower level of mobilization and slower utilization by the embryonic axes. The liberated fatty acids might be used for the formation of membrane lipids in the growing embryos. Similar results were reported by Munshi et al. (2007) in sunflower seeds.

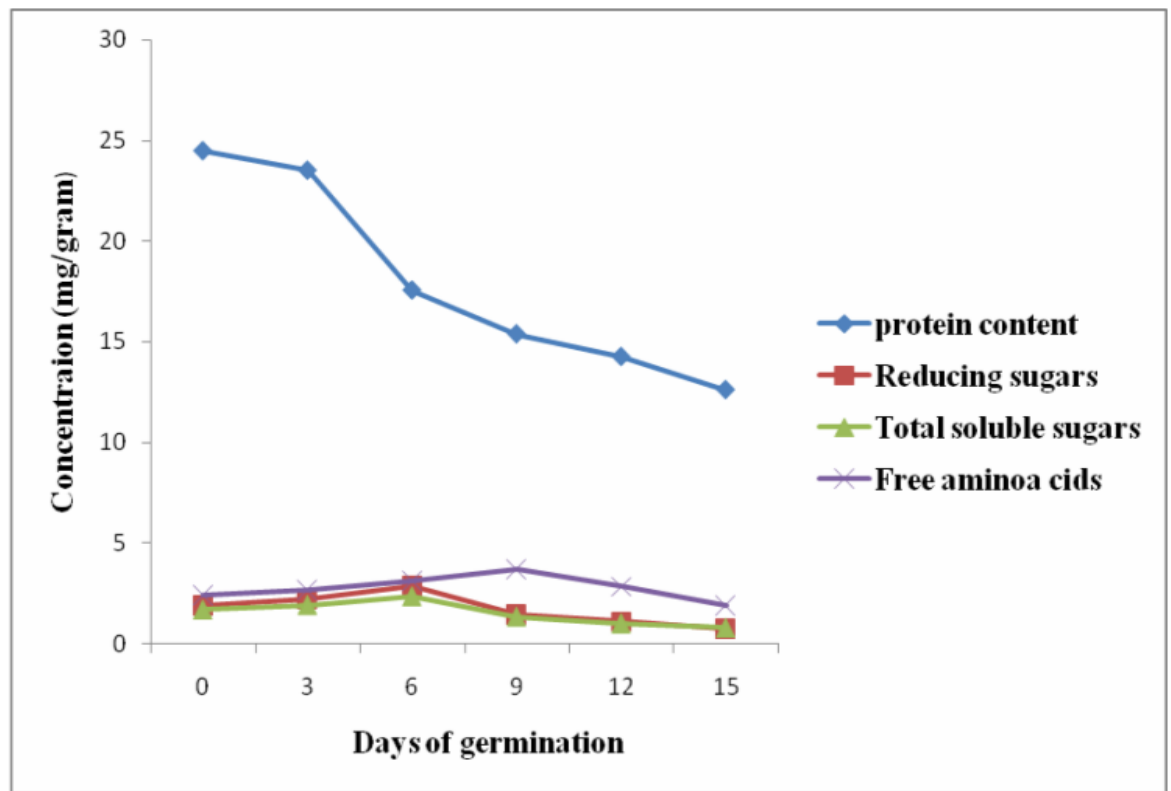

Fig. 1. Total proteins, amino acids, reducing and soluble sugar levels during seed germination (0-15 days)

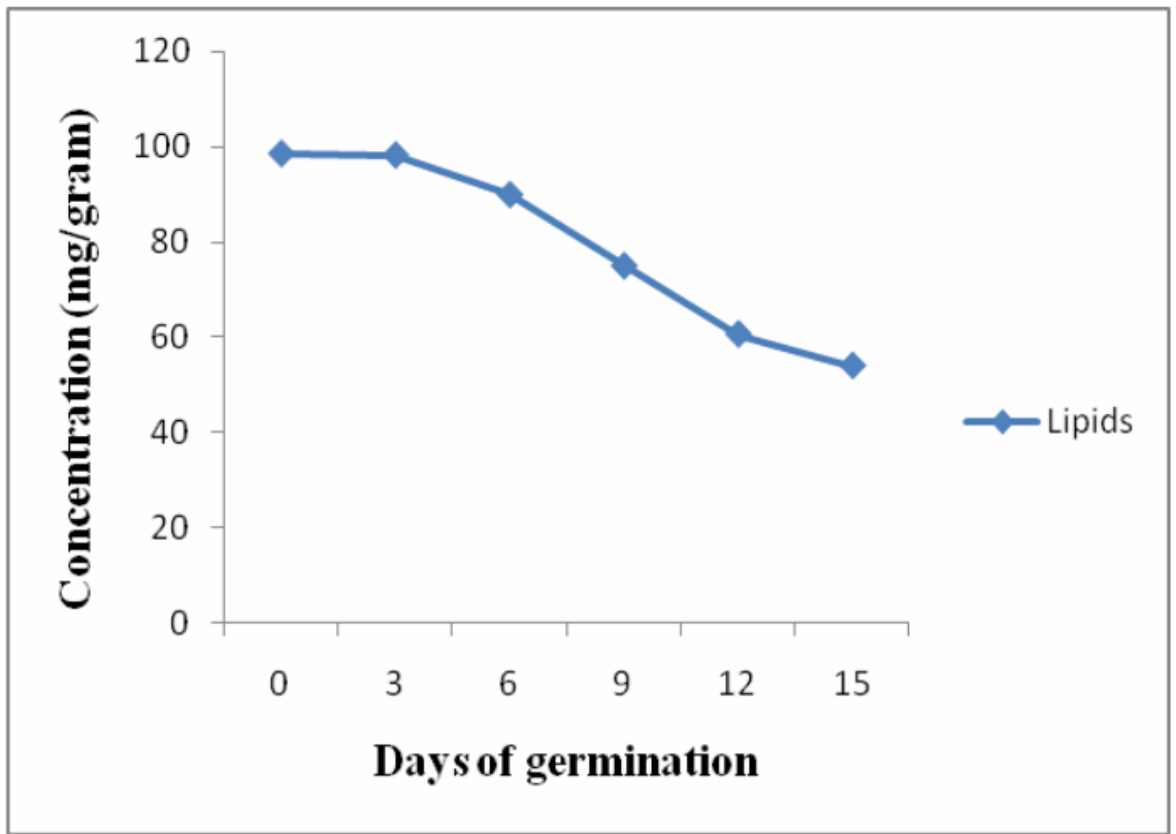

Fig. 2. Total lipid content during seed germination (0-15 days) 
108

\section{Conclusions}

The seeds of Sterculia urens were rich in proteins, lipids as well as carbohydrates and their levels decreases as the germination progress, indicating their key role in the growth of embryonic axis. The work will be further continued to know the role different enzymes involved in germination of Sterculia urens seeds and the purification of enzymes by different methods.

\section{References}

Ali Al-Heal A (1992). Growth and protein content of Cassia senna L. Seedlings. J King Saud Univ Sci 4(1):5-13.

Balasaraswathi R, Sadasivam S (1997). Changes in oil, sugar and nitrogenous components during germination of sunflower seeds, Helianthus annuus. Plant Foods Hum Nutr 51:71-77.

Becker WM, Leaver CJ, Weir EM, Riezman H (1978). Regulation of glyoxysomes enzymes during germination of cucumber. 1. Developmental changes in cotyledonary protein, RNA, and enzyme activities during germination. Plant Physiol 62:542-549.

Beevers L, Spittoesser WE (1968). Protein and Nucleic acid metabolism in germinating seeds. Peas J Experim Bot 19:698-711.

Bemfeld P (1962). Comparative Biochemistry. Vol. 3, Florkin M, Mason W (eds.). Academic Press, NY, p. 355-360.

Dubois M, Gilles KA, Hamilton JK, Rebers PA, Smith F (1956). Colorimetric Method for determination of sugars and related substances. Analytic Chem 28:350-356.

Giami SY, Chibor BS, Edebiri KE, Achinewhu SC (1999). Changes in nitrogenous and other chemical constituents, protein fractions and in vitro protein digestibility of germinating fluted pumpkin (Telfairia occidentalis Hook). Seed Plant Foods Hum Nutr 53:333-342.

Jaya TV, Venkataraman LV (1981). Changes in carbohydrate constituents of chickpea and greengram during germination. Food Chem 7(2):95.

Kern R, Chrispeels J (1978). Influence of the axis on the enzymes of protein and amide metabolism in the cotyledons of Mung Bean Seedlings. Plant Physiol 62:815-819.

Khattak GSS, Muhammad A, Tanveer E, Ghulam A (2003). Selection for large seed size at the seedling stage in mungbean (Vigna radiata (L.) Wilczek). Breed Sci 53:141-143.

Khetarpaul N, Chauhan BM (1990). Effect of germination and fermentation on available carbohydrate content of pearl millet. Food Chem 38:21-26.
Kon S, Olson AC, Frederick DP, Eggling SD, Wagner JR (1973). Effect of different treatments on phytate and soluble sugars in California small white beans (Phaseolus vulgaris). J Food Sci 38:215.

Le Page-Degivry MT, Garello G (1973). Embryo dormancy in Taxus baccata: influence of culture medium on initiation of germination. Physiol Plant 29:204-207.

Lowry OH, Rosebrough NJ, Farr AL, Randall RJ (1951). Protein measurement with folin phenol reagent. J Biol Chem 193:265-275.

Moore S, Stein WH (1954). A modified ninhydrin reagent for the photometric determination of amino acids and related compounds. J Biol Chem 211:907-913.

Obizaba IC, Egbuna HI (1992). Effect of germination and fermentation on the nutritional quality of bambara nut (Voandzeia subterranea L. Thouans) and its product (milk). Plant Foods Hum Nutr 42:13-23.

Olczak M, Niziol E, Widlak W, Morawiecka B (1992). The activity of acid phosphatase and the level of storage proteins during the early stages of germination of Lupinus luteus L. and Lupinus angustifolius L. seeds. Acta Soc Bot Pol 61:177185.

Plummer JA, Bell DT (1995). The effect of temperature, light and gibberellic acid $\left(\mathrm{GA}_{3}\right)$ on the germination of Australian everlasting daisies (Asteraceae, Tribe Inulae). Aust J Bot 43:93-100.

Rajaram N, Janardhanan K (1990). Chemical composition and nutritional evaluation of certain under-exploited Vigna spp. Food Sci Nutr 42:213-221.

Rao MS, Bhagsari AS, Mohamed AI (1998). Yield, protein, and oil quality of soybean genotypes selected for tofu production. Plant Food Hum Nutr 52:241-251.

Somogyi M (1952). Notes on sugar determination. J Biol Chem 195:19-23.

Tan-Wilson AL, Liu X, Chen R, Qi X, Wilson KA (1996). An acidic amino acid-specific protease from germinating soybeans. Phytochem 42:313-319.

The Wealth of India (1952). Raw materials, Vol. III. New Delhi, India: Council of Scientific and Industrial Research.

Yoshida K, Tsurushiin S, Fukuba H, Tadokoro T, Maekawa A (1997). Changes in protein content and enzyme activity in black matpe organs during germination Nippon-EiyoShokuryo-Gakkaishi. J Japanese Soc Nutr Food Sci 50:153159. 